\title{
Bycatch of wintering common and red-throated loons in gillnets off the USA Atlantic coast, 1996-2007
}

\author{
Melissa L. Warden* \\ Integrated Statistics, 16 Sumner Street, Woods Hole, Massachusetts 02543, USA \\ Contact address: National Marine Fisheries Service, 166 Water Street, Woods Hole, Massachusetts 02543, USA
}

\begin{abstract}
Common loons Gavia immer and red-throated loons G. stellata winter along the USA Atlantic coast, where fisheries observers have documented interactions with commercial fishing operations, largely coastal gillnets. The red-throated loon is a conservation priority for the US Fish and Wildlife Service, so interest lies in gauging fisheries bycatch relative to population levels. Gillnet fisheries observer data from 1996 to 2007 were used in developing generalized linear models to predict common and red-throated loon bycatch rates and investigate gear characteristics associated with high bycatch rates. The predicted bycatch rates were applied to commercial gillnet effort data to estimate total bycatch during this time period. Bycatch was then compared to a potential biological removal (PBR) measure that was calculated from limited demographic parameters. Factors most commonly associated with the bycatch rates were bottom depth and sea surface temperature. Common loon bycatch rates were higher for strings without spacing between nets versus strings with spacing, and for strings that fished $\geq 24 \mathrm{~h}$ versus strings that fished $<24 \mathrm{~h}$. Average annual bycatch was $74(95 \% \mathrm{CI}$ : 29-189) common loons in the Northeast, and 477 (370-615) common loons and 897 (620-1297) redthroated loons in the Mid-Atlantic. The average red-throated loon bycatch reached about $60 \%$ of the PBR measure. This estimated level of bycatch emphasizes that the red-throated loon is a conservation priority, especially considering the unknown level of bycatch in non-oceanic coastal gillnet fisheries and uncertain demographic parameters.
\end{abstract}

KEY WORDS: Bycatch mitigation $\cdot$ Commercial fishing $\cdot$ Seabird-fishery interaction $\cdot$ Gillnet $\cdot$ Atlantic $\cdot$ Red-throated loon · Common loon

\section{INTRODUCTION}

Common loons Gavia immer and red-throated loons G. stellata winter along the North American Atlantic coast, where commercial gillnet fisheries operate year round in USA state and federal waters. Comprehensive bycatch estimates for loons and other seabirds along the USA Atlantic coast are not available, although fisheries interactions have been observed and quantified (Forsell 1999, Soczek 2006, Moore et al. 2009). Fisheries interactions might be important to loon populations even if the incidental catch rate is low, because seabirds have low reproductive capacity and slow maturation, making recovery from the loss of adult birds difficult (Melvin \& Parrish 2001).
Seabird bycatch in coastal gillnet fisheries has received attention in many other regions, including Japan (DeGange \& Day 1991), the USA Pacific coast (Melvin et al. 1999, Carretta et al. 2004, Hamel et al. 2008), Newfoundland and Labrador (Benjamins et al. 2008), and the Baltic Sea (Dagys \& Žydelis 2002, Österblom et al. 2002, Žydelis et al. 2009). Along the USA Atlantic coast, Soczek (2006) estimated seabird bycatch in New England fisheries for 1994 to 2003 based on Northeast Fisheries Observer Program (NEFOP) data and percent observer coverage. The primary species bycaught in gillnet fisheries north of Cape Cod, Massachusetts, were shearwaters Puffinus spp. and gulls Larus spp., and south of Cape Cod, common loons and common murres Uria aalge. Forsell (1999) 
observed primarily red-throated and common loons bycaught in coastal gillnet fisheries from New Jersey to North Carolina.

Common loons winter along the Atlantic from Newfoundland to central Mexico and red-throated loons from Newfoundland to northern Georgia. Concentrations of commercial gillnet fishing effort overlap with the loons' distribution around Cape Cod and Rhode Island, off central New Jersey, south of Delaware Bay, the mouth of Chesapeake Bay, and off North Carolina (Fig. 1). The wintering common loon population on the Atlantic coast is estimated at 495000 to 522000 , with densities greatest off Massachusetts, Rhode Island, Virginia south of Chesapeake Bay, and North Carolina (Evers 2007). The Mid-Atlantic/New England/Maritimes Waterbird Conservation Plan (MANEM 2006: www.waterbirdconservation.org) estimated 70000 to 100000 red-throated loons wintering from the Canadian Maritimes to Virginia. Counts of red-throated loons migrating past New Jersey averaged 50400 annually during 1988 to 1992 (Sherony et al. 2000) and 58000 annually during 1993 to 1997 (Forsell 1999). Wintering populations of red-throated loons are densest near Delaware Bay and off North Carolina (Gotthardt 2001). The approximate winter range of both common and red-throated loons is inshore of the continental shelf break (i.e. the $200 \mathrm{~m}$ isobath; Powers \& Cherry 1983, Evers 2007), with both species often inhabiting bays and inlets (Gotthardt 2001, Evers 2007).

According to MANEM 2006, the common loon is a species of moderate concern in eastern USA and Canadian coastal waters. The red-throated loon is a species of high concern in the eastern USA and Canada. Neither species is listed under the USA Endangered Species Act or the Canadian Species At Risk Act, but the red-throated loon is on the USA federal list of Birds of Conservation Concern (USFWS 2008).

Loons are protected under the Migratory Bird Treaty Act (MBTA 1918), which prohibits the taking of migratory birds unless under permit by the Secretary

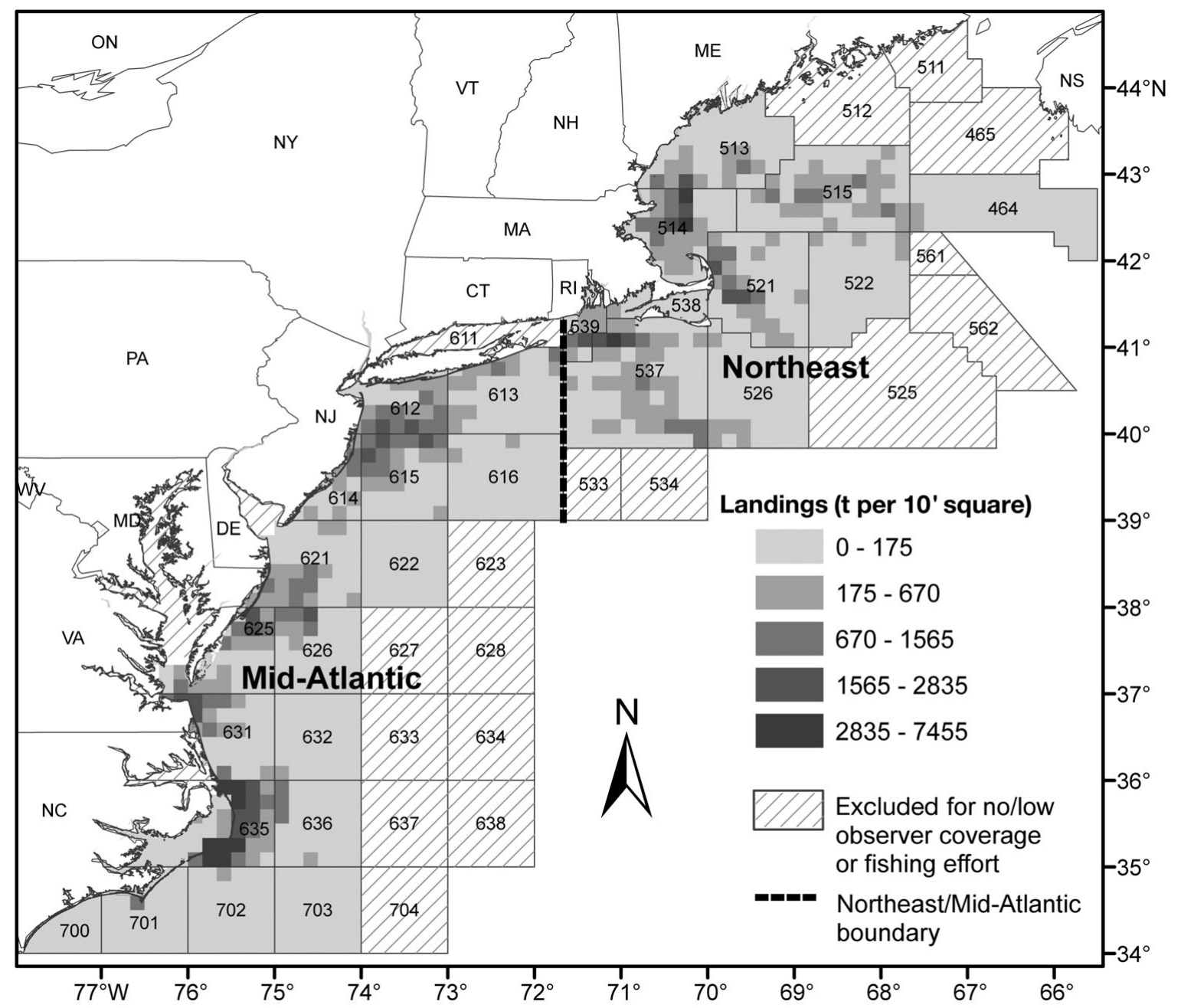

Fig. 1. Statistical areas grouped into Northeast and Mid-Atlantic regions. Adjusted commercial effort during winter (October to May 1996-2007), given as landings (t per 10' square) 
of the Interior. ${ }^{\mathbf{1}}$ The MagnusonStevens Fishery Conservation and Management Reauthorization Act of 2006 supports the MBTA by authorizing programs to reduce seabird interactions in fisheries as part of a bycatch reduction program (MSRA 2007).

The present study is a first step at addressing the lack of comprehensive Atlantic seabird bycatch estimates by examining bycatch of wintering common and red-throated loons in gillnets off of the USA Atlantic coast from 1996 to 2007, where wintering months are defined as October through May. Bycatch rates were estimated from Northeast Fisheries Observer Program (NEFOP) data, and total bycatch mortality was estimated by applying the bycatch rates to commercial fisheries data (Vessel Trip Report, Commercial Fisheries Database System, and North Carolina Division of Marine Fisheries). Fishing characteristics associated with high bycatch rates are explored and population impacts in terms of potential biological removal (PBR) concepts are presented.

\section{MATERIALS AND METHODS}

Study region. The Northeast Fisheries Science Center (NEFSC) study area from Maine through North Carolina was divided into Northeast and Mid-Atlantic regions, along NEFSC statistical areas (Fig. 1). Statistical areas with no or very low fisheries observer coverage (defined as no hauls observed during 9 or more years of the $12 \mathrm{yr}$ study period) or minimal fishing effort were not included. Inshore waters, such as bays, have historically low observer coverage and were generally not included; however, Pamlico Sound and the mouth of Chesapeake Bay were included because observer coverage was at least $0.5 \%$ of landings.

Data sources. NEFOP: NEFOP monitors commercial fishing on the USA Atlantic coast. Observers record catch compositions, including incidental bycatch of marine mammals, sea turtles, seabirds, and nontarget fish species. Observers also document vessel and gear characteristics, weather and habitat conditions (e.g. depth and sea surface temperature [SST]), longitude/

1'Take' is defined as 'pursue, hunt, shoot, wound, kill, trap, capture, or collect, or attempt to commit the above' (Definitions 1973) latitude, and statistical area. NEFOP observed approximately 23000 gillnet hauls in the Northeast and 21000 hauls in the Mid-Atlantic during January to May and October to December, 1996 to 2007. Annual observer coverage of gillnet fisheries for the defined winter season ranged from 3 to $9 \%$ in the Northeast (Table 1) and 2 to $4 \%$ in the Mid-Atlantic (Table 2).

Observed Northeast gillnet fisheries used primarily monofilament, anchored, bottom-tending nets. Typical gear consisted of a string of 5 to 15 nets (91 m each). Small-mesh nets $(<14 \mathrm{~cm}$ stretched inside knot-toknot) composed a small portion of the fishery and landed mostly spiny dogfish Squalus acanthias, bluefish Pomatomus saltatrix, and cod Gadus morhua. Large-mesh nets ( $\geq 14$ and $<20 \mathrm{~cm}$ ) were more commonly used, and landed mostly cod, pollock Pollachius virens, spiny dogfish, flounder (Paralichthyidae, Pleuronectidae), and white hake Urophycis tenuis. Extralarge-mesh nets $(\geq 20 \mathrm{~cm})$ targeted monkfish Lophius americanus and skates (Rajidae).

Observed Mid-Atlantic gillnet fisheries used primarily monofilament drift and bottom-tending nets. Typical gear consisted of a string of 1 to 10 nets of $91 \mathrm{~m}$. Small-mesh fishing gear was more common than in the Northeast, with mesh sizes as small as $6.5 \mathrm{~cm}$ that caught primarily croaker Micropogonias undulatus, bluefish, weakfish Cynoscion regalis, menhaden Brevoortia tyrannus, and spot Leiostomus xanthurus. Large-mesh nets landed mostly spiny dogfish, smooth dogfish Mustelus canis, and bluefish. Extra-large-mesh gear caught mostly monkfish, but also skates, striped bass Morone saxatilis, spiny dogfish, and Atlantic mackerel Scomber scombrus. 
Table 2. Mid-Atlantic USA gillnet fisheries: commercial fishing effort (metric $t$ landed), $\%$ observer coverage estimated as $100 \times$ (observed/total landings), observed and estimated total common and red-throated loon bycatch, CV and $95 \%$ confidence interval (CI) of estimated bycatch in winter

\begin{tabular}{|c|c|c|c|c|c|c|c|c|c|c|c|}
\hline \multirow[t]{2}{*}{ Year } & \multicolumn{2}{|c|}{ Landings (t) } & \multirow{2}{*}{$\begin{array}{c}\text { Observer } \\
\text { coverage } \\
(\%)\end{array}$} & \multicolumn{4}{|c|}{ Common loon bycatch -} & \multicolumn{4}{|c|}{-Red-throated loon bycatch } \\
\hline & Total & Observed & & $\begin{array}{c}\text { Ob- } \\
\text { served }\end{array}$ & $\begin{array}{c}\text { Estimated } \\
\text { total }\end{array}$ & $\mathrm{CV}$ & $\mathrm{CI}$ & $\begin{array}{c}\text { Ob- } \\
\text { served }\end{array}$ & $\begin{array}{l}\text { Estimated } \\
\text { total }\end{array}$ & $\mathrm{CV}$ & $\mathrm{CI}$ \\
\hline 1996 & 21330 & 500 & 2.3 & 1 & 331 & 0.25 & $(203,540)$ & 0 & 483 & 0.19 & $(331,704)$ \\
\hline 1997 & 19870 & 460 & 2.3 & 5 & 774 & 0.23 & $(499,1201)$ & 46 & 4059 & 0.46 & $(1719,9585)$ \\
\hline 1998 & 20590 & 610 & 3.0 & 38 & 1294 & 0.22 & $(848,1975)$ & 22 & 649 & 0.37 & $(321,1311)$ \\
\hline 1999 & 17160 & 320 & 1.9 & 44 & 919 & 0.25 & $(566,1491)$ & 33 & 932 & 0.18 & $(653,1329)$ \\
\hline 2000 & 12540 & 280 & 2.2 & 19 & 770 & 0.23 & $(494,1200)$ & 28 & 426 & 0.30 & $(239,759)$ \\
\hline 2001 & 10770 & 350 & 3.2 & 18 & 161 & 0.28 & $(93,278)$ & 12 & 203 & 0.35 & $(105,394)$ \\
\hline 2002 & 10200 & 160 & 1.6 & 3 & 203 & 0.30 & $(114,363)$ & 2 & 1042 & 0.39 & $(498,2183)$ \\
\hline 2003 & 11320 & 170 & 1.5 & 5 & 357 & 0.30 & $(199,640)$ & 46 & 370 & 0.26 & $(225,610)$ \\
\hline 2004 & 9740 & 290 & 3.0 & 2 & 274 & 0.23 & $(177,424)$ & 2 & 536 & 0.44 & $(236,1216)$ \\
\hline 2005 & 8500 & 350 & 4.1 & 7 & 268 & 0.23 & $(173,416)$ & 0 & 356 & 0.19 & $(247,513)$ \\
\hline 2006 & 6820 & 300 & 4.4 & 1 & 107 & 0.25 & $(66,172)$ & 0 & 135 & 0.33 & $(73,252)$ \\
\hline 2007 & 9810 & 340 & 3.5 & 5 & 262 & 0.27 & $(156,439)$ & 8 & 1567 & 0.25 & $(963,2550)$ \\
\hline $\begin{array}{l}\text { Mean } \\
\text { annual }\end{array}$ & & & & & 477 & 0.13 & $(370,615)$ & & 897 & 0.19 & $(620,1297)$ \\
\hline Total & 158650 & 4130 & 2.6 & 148 & 5720 & 0.13 & $(4438,7372)$ & 199 & 10758 & 0.19 & $(7438,15561)$ \\
\hline
\end{tabular}

The observer data were augmented with environmental data and with derived values for missing data. Environmental data were acquired electronically and imported into ArcGIS 9.2. The bottom depth (from National Geophysical Data Center or Shuttle Radar Topography Mission bathymetry datasets), bottom slope, distance from the coast, and SST (from MODIS Aqua, MODIS Terra, GOES, and AVHRR Pathfinder satellite data, or from Jet Propulsion Laboratory climatology) were sampled at each NEFOP fishing location. The North Atlantic Oscillation (NAO) index was also added to the NEFOP dataset. If bottom depth or SST was missing from the NEFOP record, it was filled in from GIS sources. Missing values for other variables of interest were generally derived from the median value of strata involving the same fishing trip or the same vessel, gear type, year, and month. For details on the acquisition of environmental variables and imputation of missing values, see Warden \& Orphanides (2008).

For SST in North Carolina, the GIS-acquired values showed anomalies compared to NEFOP values (possibly due to poor detection of the Gulf Stream front), so the GIS-acquired SST values were not used. Instead, missing SST values for NEFOP hauls in North Carolina were predicted from non-missing values regressed against combinations of month, year, statistical area, and a smaller $10^{\prime}$ square area.

Most NEFOP variables of interest had $<4 \%$ missing values, and many had $<1 \%$. Hauls with variables of interest still missing after imputation were removed from analysis, resulting in retention of $>99.5 \%$ of observed hauls.

Vessel trip reports (VTR): Fishers with federally permitted vessels are mandated (RARR 1996) to report all landings and discards via a VTR. Trip-level information reported on the VTR includes the number of hauls, average bottom depth, primary longitude/latitude and statistical area fished, gear type, average mesh size, average number and length of nets, and average length of time nets were in the water (i.e. soak duration). The VTR data were augmented with environmental variables in the same manner as the NEFOP data (see previous section).

Approximately $10 \%$ of VTR trips lacked data on longitude and latitude. Missing locations were imputed from either matching NEFOP trips ( $0.3 \%$ of total trips), from VTR information recorded on the same vessel $(7 \%)$, or from a regression based on depth, statistical area, month, and species caught $\left(2.2 \% ; \mathrm{R}^{2}=0.98\right)$. Remaining trips with missing locations $(0.5 \%)$ were excluded.

Commercial Fisheries Database System (CFDBS): Federally permitted dealers are mandated to report landed seafood purchases (RARR 1996). Dealer information is contained in the CFDBS maintained by the National Marine Fisheries Service, and includes the date, port, species, weight, and grade of the purchase. Fishing location is not included.

North Carolina Division of Marine Fisheries (NCDMF): NCDMF data are more complete than CFDBS data for North Carolina (Orphanides \& Palka 2008). The data include landings, gear type, date and county of landing, and water body fished. Longitude/ latitude or statistical area fished is not indicated. All trips from the NCDMF data that were oceanside or in Pamlico Sound were generally retained. However, because NEFOP hauls south of $34^{\circ} \mathrm{N}$ latitude were removed, as they were outside the study area, a corresponding percentage of fishing effort from the NCDMF dataset was also removed. 
Effort dataset: The VTR dataset represented the primary source of information on gillnet fisheries effort. The unit of effort was metric tons landed, because other measures of effort (e.g. soak duration or net length) are not well presented in the VTR dataset (Orphanides \& Palka 2007). Because VTR data are subject to underreporting (Murray 2009, Palmer \& Wigley 2009), VTR landings were adjusted using CFDBS landings. Dealer transactions with sufficient information in the CFDBS have been matched by the NEFSC to the corresponding VTR trip (Wigley et al. 2008). For VTR trips with 1-to-1 matches in the CFDBS, the total dealer-reported landings for the trip were used in lieu of the total reported on the VTR. This accounted for about $75 \%$ of Northeast trips and just under $50 \%$ of Mid-Atlantic trips. VTR and CFDBS records with no matches were stratified by state, year, and season (which varied by state according to fishing patterns). If the total landings for a stratum were lower in the VTR than in the CFDBS, then the landings for each VTR trip in the stratum were multiplied by the ratio of the CFDBS to VTR landings for the stratum. If the VTR landings for the stratum were greater than or equal to the CFDBS landings, then the VTR landings for the stratum were unadjusted. This assumed that the CFDBS landings may have been underrepresented in some strata, in which case the VTR landings presented a more complete picture of total effort.

VTR data are not representative of fishing effort in North Carolina (Orphanides \& Palka 2008), so NEFOP haul information served as the base effort dataset for that state. NEFOP landings were stratified by year and season and were adjusted with NCDMF data in the same way that VTR data were adjusted with CFDBS.

Statistical analysis. Bycatch estimation: The bycatch rate was defined as the number of observed takes per metric ton (t) of fish landed (incremented by $0.001 \mathrm{t}$ to allow for 0 landings) on each independent haul. A take was defined as an observed mortality. The bycatch rate was modeled as a Poisson generalized linear model (GLM) using R statistical computing software (version 2.7.0; R Development Core Team 2008). Separate analyses were conducted for common loons in the Northeast, common loons in the Mid-Atlantic, and red-throated loons in the Mid-Atlantic (no red-throated loon takes were observed in the Northeast). Loons unidentified to the species level were not included. One-quarter to onethird of the dataset was randomly selected as a holdout dataset for model validation; the rest of the data were retained as a training dataset for model fitting.

Poisson models of biological data are commonly overdispersed, often resulting from homogeneous responses by species that congregate (Burnham \& Anderson 2002) or from unmeasured heterogeneity in the population (Agresti 1996). The latter implies that inclusion of all relevant predictors may be necessary for equidispersion. The dispersion parameter $(\hat{c})$ of each GLM was estimated by the Pearson statistic $\left(X^{2}\right)$ divided by its degrees of freedom (Agresti 1996).

Potential predictors: For model selection, predictors were chosen a priori from the $>200$ variables in the NEFOP database, limited to variables well represented in the VTR dataset. The variables chosen included static environmental factors (bottom depth in $\mathrm{m}$, distance from the coastline in $\mathrm{km}$, and bottom slope), dynamic environmental factors (SST and the winter index of the North Atlantic Oscillation [WNAO, with a lag of 0, 1, or $2 \mathrm{yr}])$, gear characteristics (mesh size in inches), and time/area factors (an indicator of state landed or statistical areas fished, and an aggregate year indicator [1996-2000, 2001-2007]). Quadratic terms for continuous variables were considered.

Bottom depth, bottom slope, and SST are recognized predictors of seabird distribution (Balance et al. 2001). Bottom depth has been used to characterize loon habitat and foraging behavior. Haney (1990) observed common loons primarily in waters that were $\leq 40 \mathrm{~m}$ deep, with a peak at $\leq 20 \mathrm{~m}$. Common loons have been recorded diving to depths of 30 to $40 \mathrm{~m}$ in pursuit of fish and crabs (McIntyre 1978, Haney 1990). Redthroated loons tend to forage in shallow waters with dives generally less than $10 \mathrm{~m}$ deep (Gotthardt 2001).

Distance from the coastline was considered in addition to bottom depth because loons are primarily coastal and because bathymetry is sometimes varied as distance from the coastline increases, particularly in the Northeast. Powers \& Cherry (1983) recorded common loons mainly within $60 \mathrm{~km}$ of the coast in states south of Long Island, New York, but as far as $160 \mathrm{~km}$ off Cape Cod. Red-throated loons were found offshore less frequently than common loons.

The NAO indirectly influences seabird populations as a proxy for climatic changes that affect the abundance and distribution of prey (Durant et al. 2004, Sandvik \& Erikstad 2008). A lag of several years may be evident. On a nonlagged basis, NAO is related to weather conditions such as temperature, wind, and precipitation (Hurrell 1995). Researchers have linked it to changes in migration timing (Rainio et al. 2006) and adult survival (Sandvik \& Erikstad 2008) in some seabirds. The NAO winter index (the average of the monthly index for December through March) contains less noise than the monthly index (Sandvik \& Erikstad 2008).

To capture differences in fishing practices and loon distribution, a region indicator was defined in the MidAtlantic according to the state of landing (aggregated into North Carolina, Virginia, Maryland and Delaware, and other states to the north). In the Northeast, an aggregate statistical area indicator was used to represent the Gulf of Maine (statistical areas <525) or south- 
ern New England ( $>525$; see Fig. 1). Because NAO effects can vary by geographic region (Sandvik \& Erikstad 2008), an interaction between the region variable and WNAO was considered. The post-2000 year indicator was considered because of changes in gillnet fisheries, namely closures of the spiny dogfish fishery (NMFS 2000) and the phasing out of the oceanintercept shad fishery (ASMFC 1999), which saw almost half of the observed red-throated loon takes. Mesh size was used as a proxy for the target species being fished.

Model selection: Following Burnham \& Anderson (2002), model selection was done using Akaike's Information Criterion (AIC) adjusted for overdispersion (QAIC). Models with lower AIC are preferred, and evidence for a particular model can be summarized by the AIC weight. The AIC weights for all models under consideration sum to 1 . The ratio of 2 AIC weights (i.e. the evidence ratio) provides a measure of how probable a model is over another.

Modeling was carried out using all possible combinations of the a priori variables, with restrictions to be described. The number of model parameters was limited to be no greater than 1/10 the number of positive events (Peduzzi et al. 1996); however, if data were sparse (fewer than 50 takes observed), then 1/6 was used. All models with the maximum number of parameters were considered as a set of global models. Because these data were likely overdispersed, $\hat{C}$ was determined for each global model. The lowest $\hat{c}$ was taken as the global estimate used for calculating QAICs for model selection (Burnham \& Anderson 2002).

If the data could support at least 10 parameters, models with fewer than 4 parameters were considered unlikely and were not fitted. Of the fitted models, those with $\hat{c}>6$ were dismissed as having an inadequate mean structure (Burnham \& Anderson 2002). Models were also eliminated if the predicted number of takes on the holdout dataset differed from the actual number by $>30 \%$.

Ranked QAIC weights for the remaining models were summed to obtain the set of candidate models that contained $90 \%$ of the cumulative QAIC weight. Following Richards (2008), a candidate model was eliminated if a smaller candidate model comprised a subset of the larger model's parameters and had a lower QAIC.

To assess the fit of the candidate models, continuous variables were pooled to create informative strata. A formal goodness-of-fit test encompassing all strata was not possible due to 0 expected counts in numerous cells, violating the chi-square assumption, but informal comparisons of the predicted to the observed number of takes across more limited strata were performed. The generalizability of a model was assessed by comparing parameter coefficients obtained by fitting the model to the holdout dataset versus the training dataset (Kutner et al. 2005). Variance inflation factors
(VIFs), which are the diagonal elements of the inverse correlation matrix of the predictor variables, were examined for evidence of multicollinearity. VIFs $>10$ indicate influential multicollinearity problems (Kutner et al. 2005).

Residuals for count data with a small mean and few distinct values are not very useful for assessing model fit. Generally, individual values are poorly predicted (Cameron \& Trivedi 1998) and residuals are not normally distributed (Agresti 1996). To remedy this, residual analysis was done with randomized quantile residuals (Dunn \& Smyth 1996) obtained from the R statmod package (Smyth 2008). Quantile residuals consist of the standard normal quantile of the inverse of the estimated Poisson distribution function at each observation. Randomization is used to obtain continuous, normally distributed residuals.

Adequate candidate models from the training data were refit to the full data (training and holdout data combined). A global $\hat{c}$ for the full data was determined using either $\hat{c}$ from the most highly parameterized candidate model or a weighted average (based on AIC weights) of $\hat{C}$ if several models had the same number of parameters (Burnham \& Anderson 2002). To eliminate numerous models with minimal contribution, the number of candidate models was reduced and QAIC weights refit so that all selected models had a QAIC weight of at least $10 \%$.

Application to VTR: Total bycatch mortality was estimated by applying the bycatch rates from all selected models to the adjusted commercial effort dataset. A weighted average of predicted bycatch was obtained using the QAIC weights. Model variances were obtained by bootstrap resampling of the NEFOP data at the haul level. Model-averaged coefficients of variation (CVs), which account for model selection uncertainty (Burnham \& Anderson 2002), were calculated for total, annual, and average annual bycatch estimates. Model-averaged confidence intervals (CI) were calculated from the CVs, assuming a lognormal distribution for the bycatch estimates.

Fishing characteristics: Fishing gear and haul characteristics in the NEFOP data were generally not considered for the bycatch estimation because most are not available from the VTR data. An exploratory GLM of the NEFOP data was developed to determine which fishing characteristics might be related to common loon bycatch. Potential predictors included those used for the bycatch estimation, plus additional gear and haul characteristics (Table 3). An exploratory model was not developed for red-throated loon bycatch because numerous hauls with observed red-throated loon takes had unrecorded gear information. Because of the large number of potential variables, a forward stepwise procedure was conducted, adding at each 
Table 3. Additional Northeast Fisheries Observer Program gear and haul characteristics considered in the exploratory models

Average height of net

Average length of individual net panel

Average number of vertical meshes of a net

Average ratio of the length of the floatline to the length of

the stretched-out net

Color of the netting

Diameter of the twine used

Indicator for whether:

- an active marine mammal deterrent device (i.e. pinger) was used

- an anchor(s) was used on the string

- floats were used on the string

- the observer watched the net exclusively during haulback

- spaces of at least 2 feet $(\sim 60 \mathrm{~cm})$ separated the nets on the string

- tiedowns were used

Length of the haulback time, from start until entire gear

was out of the water

Length of time the string was in the water

Number of nets on the string

Time the haul began, categorized into dawn, day, dusk, night

Total length of the gillnet string

Total weight of anchors used to secure the string

Total weight of leadline used

Wave height at beginning of haul

Weather conditions during the haul, categorized into clear, cloudy, or precipitation/fog

step the variable that most reduced the AIC of the GLM and did not contribute to overdispersion. Associations with the bycatch rate were further explored through a generalized additive model (GAM), which uses splines to allow nonlinear relationships.

PBR-type measure of sustainable removal: $P B R$ is commonly used for assessing the level of humancaused mortality that can be sustained by marine mammal populations. PBR is defined as

$$
\mathrm{PBR}=\frac{1}{2} R_{\max } N_{\min } f
$$

where $R_{\max }$ is the maximum net productivity rate (i.e. the rate of annual recruitment minus mortality), $N_{\min }$ is the minimum population estimate, and $f$ is a recovery factor between 0.1 and 1.0 (Wade 1998). Use of $N_{\min }$ accounts for uncertainty in the abundance estimate; $f$ accounts for population status or data uncertainties and biases. Small values of $f$ will reduce the PBR and potentially allow for faster population recovery. Humancaused mortality levels above the PBR level may lead to population depletion (Wade 1998).

PBR-type concepts have been used to assess the status of seabird populations with limited demographic information using the following:

$$
\begin{gathered}
R_{\max }=\lambda_{\text {max }}-1 \\
\lambda_{\text {max }}=\exp \left[\left(\alpha+\frac{s}{\lambda_{\text {max }}-s}\right)^{-1}\right]
\end{gathered}
$$

and

$$
N_{\min }=\hat{N} \exp \left(Z_{0.2} \mathrm{CV}_{\hat{N}}\right)
$$

where $\lambda_{\max }$ is the population growth rate under optimal conditions, $\alpha$ is the age at first breeding, $s$ is the adult survival rate, $\hat{N}$ is the best estimate of population size, $Z_{0.2}$ the 20th percentile standard normal variate, and $\mathrm{CV}_{\hat{N}}$ is the coefficient of variation of $\hat{N}$ (Niel \& Lebreton 2005, Dillingham \& Fletcher 2008, Žydelis et al. 2009). For the present analyses, the term PBR refers to potential biological removal that was calculated with these equations.

PBR was calculated using the best available demographic parameters and population estimates, with an assumed $\mathrm{CV}_{\hat{N}}$ of 0.5 , as recommended by Dillingham \& Fletcher (2008) when uncertainty is unquantified. Recovery factors of $0.5,0.3$, and 0.1 represented a population status of "least concern," "near threatened," and "threatened," respectively (Dillingham \& Fletcher 2008). Following Žydelis et al. (2009), 95\% confidence intervals were formed by calculating PBR using the $95 \%$ confidence bounds of adult survival if available.

For common loons, necessary demographic parameters were generally available from the literature. About $85 \%$ of the 500000 common loons that winter on the North American Atlantic do so along the USA east coast (D. Evers pers. comm.), so 425000 was used as a best population estimate of common loons that are subject to bycatch in the gillnet fisheries. The age at first breeding is at least 4 yr (Grear et al. 2009) but averages 6 yr (Evers 2007), so both values were investigated. Mitro et al. (2008) estimated adult survival in northern US populations as 0.92 (95\% CI: 0.89-0.95). The recovery factor $f$ was set to 0.5 because the species is of moderate concern (MANEM 2006).

For red-throated loons, 70000 was used as a conservative population estimate based on the 70000 to 100000 range in MANEM 2006 and the counts of $<60000$ in Sherony et al. (2000) and Forsell (1999). Little information is available on other demographic parameters for North American populations. However, for European populations the age at first breeding and adult survival have been estimated at $3 \mathrm{yr}$ and 0.84 (95\% CI not available), respectively (Hemmingsson \& Eriksson 2002). Because demographic parameters might be comparable to those of related species (Dillingham $\&$ Fletcher 2008), the range of adult survival for common loons or Arctic loons (0.89; 95\% CI: 0.87-0.91; Nilsson 1977) was also considered as a possible range for red-throated loons. Also, because red-throated loon populations in Alaska declined by 53\% from 1977 to 1993 (Groves et al. 1996) and they are of conservation concern but are not listed as threatened under the Endangered Species Act, $f$ was set to 0.3. 


\section{RESULTS}

\section{Bycatch estimation}

\section{Northeast}

Observers recorded 31 incidental takes of common loons (Fig. 2, Tables $1 \& 4$ ) and no red-throated loons. The 29 hauls with takes consisted of 27 hauls with a single bird taken and 2 hauls with 2 birds taken. No birds were alive when hauled on deck.

The model-averaged, estimated total common loon mortality for 1996 to 2007 was 891 birds (95\% CI: 347-2286), with an annual average estimate of 74 (29-189; Table 1). Seven models were fit to the full data (Table 5), with estimated dispersion parameters around 2.5 to 3 . With 31 observed takes, 5 model parameters were allowed. Depth and SST were in every model, which suggests their importance relative to the other variables in explaining common loon bycatch. Four final models were selected so that their QAIC weights were at least $10 \%$. Distance from the coastline was also included in each of the final models.

\section{Mid-Atlantic}

Observers recorded 148 incidental takes of common loons and 199 red-throated loons (Fig. 2, Table 2); 70 loons unidentified to species were removed from the analysis.

Common loons. The observed common loon takes (Table 4) occurred on 92 hauls 69 with a single take, 11 with 2 takes, and 12 with $>2$ takes (maximum =7). Additional observed interactions included 3 live common loons that were removed from the analysis in order to estimate bycatch mortality.

Model-averaged, estimated total common loon mortality for 1996 to 2007 was 5720 birds (95\% CI: 4438-7372), with an average annual estimate of 477 (370-615) (Table 2); 14 models were fit to the full data (Table 5), with estimated dispersion parameters around 5.5 to 5.9. With 148 takes, 14 model parameters were allowed. Depth, SST, and the 1 or 2 yr lag of WNAO were in every model, which suggests their importance relative to the other variables
Table 4. Gavia immer and G. stellata. Percentage of observed takes and observed gillnet fishing effort (landings), stratified by month, depth, sea surface temperature (SST) and mesh size

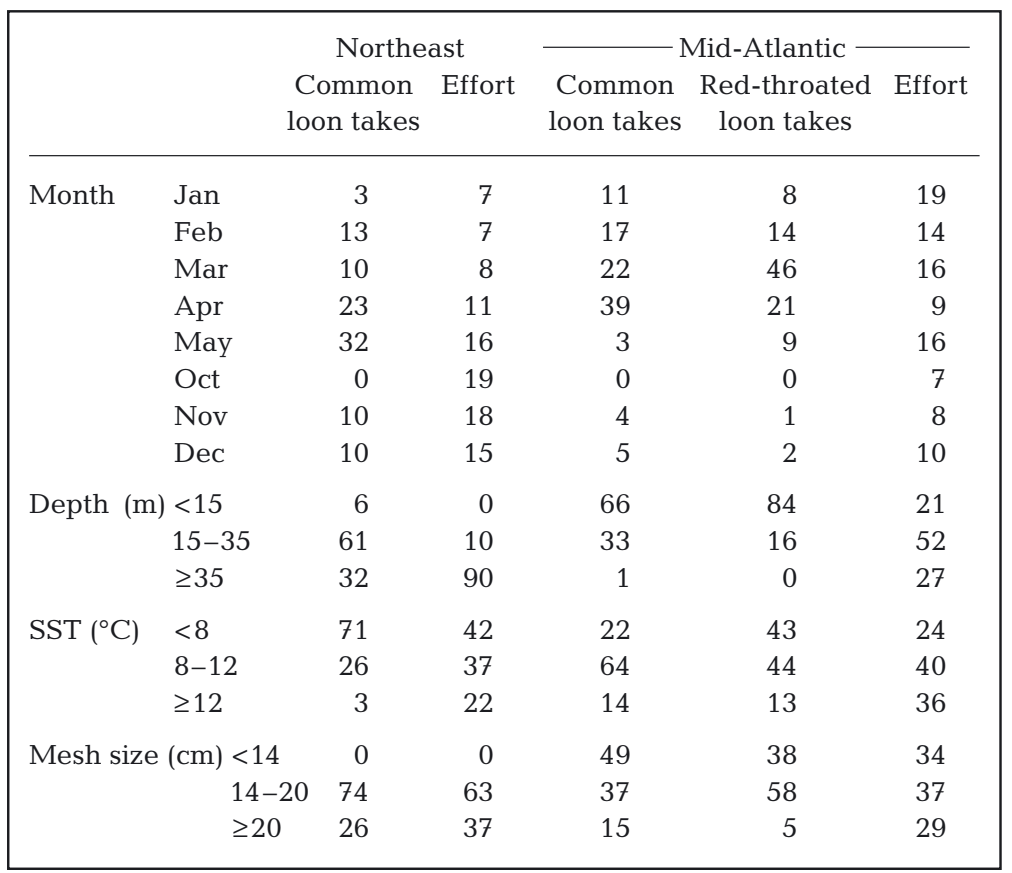

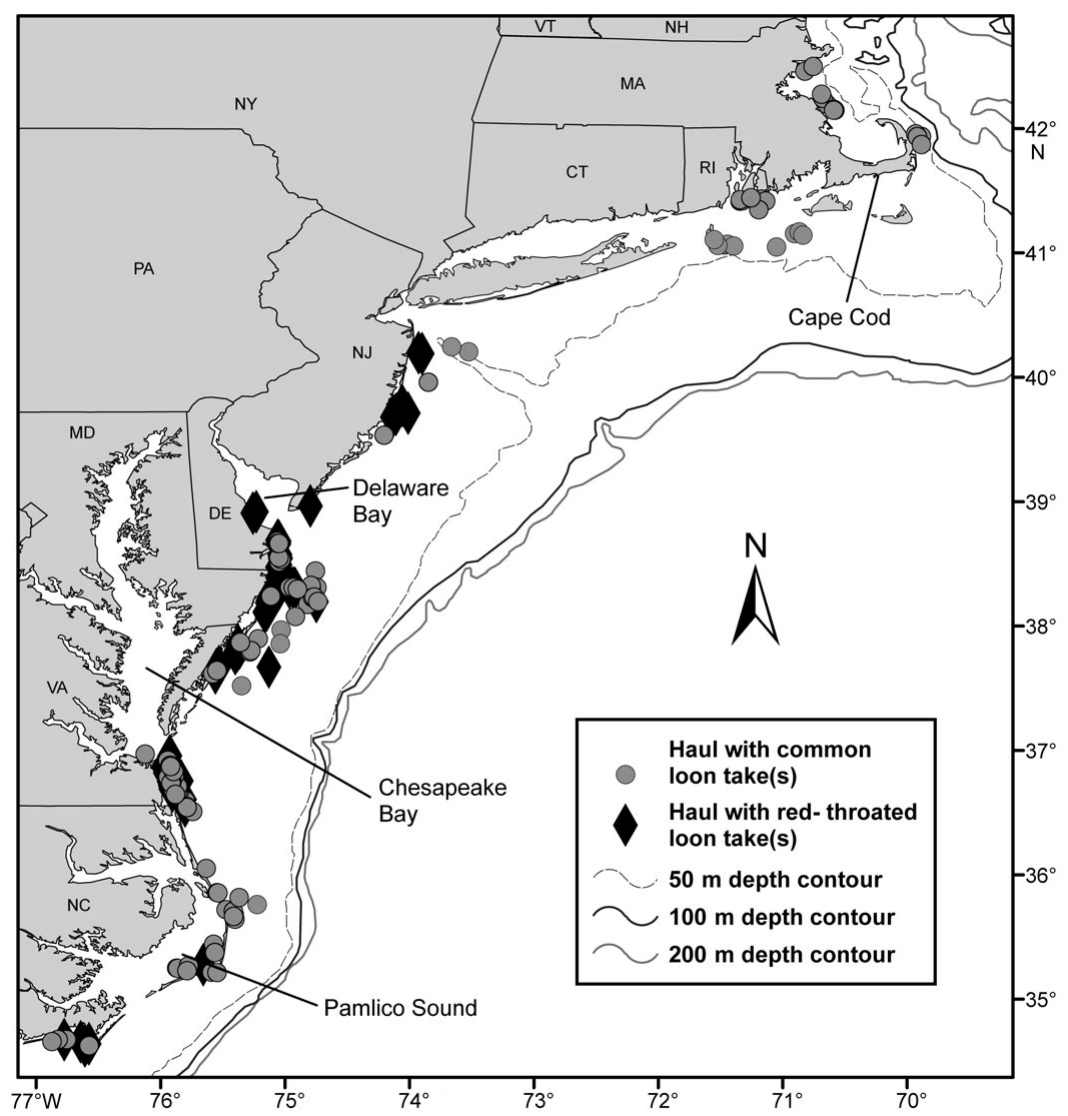

Fig. 2. Observed hauls with common loon or red-throated loon takes in Northeast and Mid-Atlantic gillnet fisheries, 1996-2007 
in explaining common loon bycatch. Four final models were selected so that their QAIC weights were at least $10 \%$. Mesh size and the aggregate state indicator were also included in each of the final models.

Red-throated loons. Observed red-throated loon takes (Table 4) occurred on 106 hauls -66 with a single take, 17 with 2 takes and 23 with $>2$ takes (maximum $=10$ ). Additional observed interactions included 4 live red-throated loons, which were removed from the analysis in order to estimate bycatch mortality, and 2 red-throated loons inside Delaware Bay, which was not included in the analysis.

Model-averaged, estimated total red-throated loon mortality for 1996 to 2007 was 10758 birds (95\% CI: 7438-15561), with an average annual estimate of 897 (620-1297) (Table 2); 3 models were fitted to the full data (Table 5), with estimated dispersion parameters around 3 to 5.5. With 199 takes, 20 parameters were al- lowed. Distance from the coast, mesh size, WNAO, the state indicator, and the interaction between state and WNAO were included in every model, suggesting their importance relative to the other variables in explaining red-throated loon bycatch. Two final models were selected so that their QAIC weights were at least $10 \%$.

\section{Model fit}

The fit of the final models was good for strata combined over 2 to 3 covariates (Fig. 3). Parameter coefficients between training and holdout datasets varied moderately and were all the same sign. All VIFs were $<3$, indicating no severe multicollinearity effects. Randomized quantile residuals showed poor fit for large counts, which is not unexpected for data with mostly zeros and few large counts. No grievous departures from model assumptions were seen.

Table 5. Information criteria for the candidate generalized linear models to predict common loon and red-throated loon bycatch mortality in Northeast and Mid-Atlantic gillnet fisheries, 1996-2007. The dispersion parameter $(\hat{c})$ is estimated for each model and is not included in the number of model parameters (k). Akaike's Information Criterion (AIC) adjusted for overdispersion (QAIC) weights and the cumulative QAIC weight are shown for all candidate models, as is the weighting scheme for the final models selected, each with a weight of at least $10 \%$. SST: sea surface temperature; WNAO: winter index of the North Atlantic Oscillation

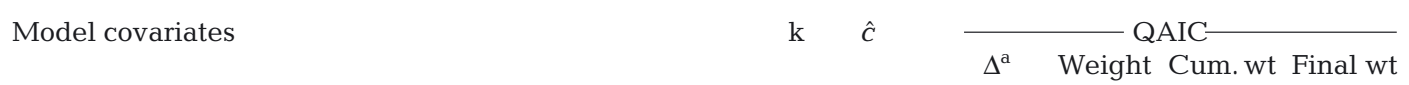

\section{Common loon, Northeast}

1 Depth, distance from coast, SST, WNAO

2 Depth, distance from coast, SST, year group

3 Area group, depth, distance from coast, SST

4 Depth, distance from coast, SST

5 Depth, distance from coast, SST, 2-yr lag WNAO

6 Area group, depth, SST, year group

7 Area group, depth, mesh size, SST

\section{Common loon, Mid-Atlantic}

1 Depth, mesh size, SST, SST ${ }^{2}$, state group, 2-yr lag WNAO, year group

2 Depth, mesh size, SST, $\mathrm{SST}^{2}$, state group, 1-yr lag WNAO, 1-yr lag $\mathrm{WNAO}^{2}$, year group

3 Depth, distance from coast, mesh size, SST, state group, 2-yr lag WNAO, year group

4 Depth, mesh size, SST, $\mathrm{SST}^{2}$, state group, 2-yr lag WNAO

5 Bottom slope, depth, mesh size, SST, $\mathrm{SST}^{2}, 2$-yr lag WNAO, year group

6 Depth, SST, $\mathrm{SST}^{2}$, state group, 1-yr lag WNAO, 1-yr lag WNAO ${ }^{2}$

7 Depth, mesh size, SST, $\mathrm{SST}^{2}$, state group, 1-yr lag WNAO, 1-yr lag WNAO ${ }^{2}$

8 Depth, SST, $\mathrm{SST}^{2}, 2$-yr lag WNAO, year group

9 Depth, mesh size, SST, state group, 2-yr lag WNAO, year group

10 Depth, mesh size, SST, $\mathrm{SST}^{2}, 2$-yr lag WNAO, year group

11 Bottom slope, depth, SST, SST 2 , 2-yr lag WNAO

12 Depth, distance from coast, mesh size, SST, state group, 2-yr lag WNAO

13 Bottom slope, depth, mesh size, mesh size $^{2}, \mathrm{SST}_{1} \mathrm{SST}^{2}, 2$-yr lag WNAO

14 Depth, mesh size, SST, state group, 2-yr lag WNAO

\section{Red-throated loon, Mid-Atlantic}

1 Depth, depth ${ }^{2}$, distance from coast, mesh size, SST, state group, WNAO, WNAO ${ }^{2}, \mathrm{WNAO} \times$ state group, year group

2 Distance from coast, mesh size, mesh size ${ }^{2}$, state group, WNAO, $\mathrm{WNAO}^{2}, \mathrm{WNAO} \times$ state group

3 Depth, depth ${ }^{2}$, distance from coast, mesh size, $\mathrm{SST}_{1} \mathrm{SST}^{2}$, state group, WNAO, WNAO ${ }^{2}$, WNAO $\times$ state group

\begin{tabular}{|c|c|c|c|c|c|}
\hline 5 & 2.89 & 0.00 & 0.34 & 0.34 & 0.40 \\
\hline 5 & 2.27 & 0.77 & 0.23 & 0.57 & 0.27 \\
\hline 5 & 2.66 & 1.61 & 0.15 & 0.73 & 0.18 \\
\hline 4 & 2.63 & 2.01 & 0.13 & 0.85 & 0.15 \\
\hline 5 & 2.84 & 3.13 & 0.07 & 0.92 & \\
\hline 5 & 4.77 & 4.35 & 0.04 & 0.96 & \\
\hline 5 & 3.95 & 4.52 & 0.04 & 1.00 & \\
\hline 10 & 5.73 & 0.00 & 0.42 & 0.42 & 0.56 \\
\hline 11 & 5.61 & 1.71 & 0.18 & 0.60 & 0.24 \\
\hline 10 & 5.71 & 3.43 & 0.08 & 0.68 & 0.10 \\
\hline 9 & 5.74 & 3.47 & 0.07 & 0.75 & 0.10 \\
\hline 8 & 5.78 & 3.63 & 0.07 & 0.82 & \\
\hline 9 & 5.89 & 4.76 & 0.04 & 0.86 & \\
\hline 10 & 5.51 & 5.37 & 0.03 & 0.89 & \\
\hline 6 & 5.52 & 5.38 & 0.03 & 0.92 & \\
\hline 9 & 5.28 & 5.40 & 0.03 & 0.95 & \\
\hline 7 & 5.04 & 5.82 & 0.02 & 0.97 & \\
\hline 6 & 5.90 & 7.21 & 0.01 & 0.98 & \\
\hline 9 & 5.52 & 7.29 & 0.01 & 0.99 & \\
\hline 8 & 5.70 & 7.36 & 0.01 & 1.00 & \\
\hline 8 & 5.57 & 9.33 & $<0.01$ & 1.00 & \\
\hline 15 & 2.95 & 0.00 & 0.53 & 0.53 & 0.53 \\
\hline 12 & 5.49 & 0.28 & 0.46 & 0.99 & 0.47 \\
\hline 15 & 4.37 & 7.94 & 0.01 & 1.00 & \\
\hline
\end{tabular}




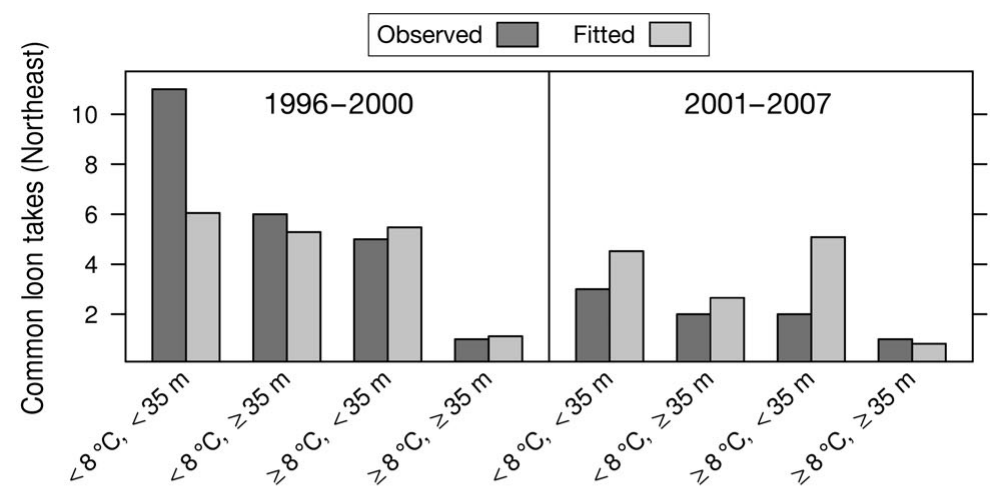

its association with the bycatch rate. About $65 \%$ of observed takes and $38 \%$ of observed landings occurred in strings without spaces between nets. Controlling for the other factors in the model, the bycatch rate for strings without spaces was 4.6 (95\% CI: 2.2-10.0) times the rate for strings with spaces.

In comparison to the bycatch estimation models, the inclusion of relevant fishing characteristics (i.e. space between nets) improved the mean structure (evidence ratio for exploratory model against top bycatch estimation model fit to same dataset $=2.3$ )

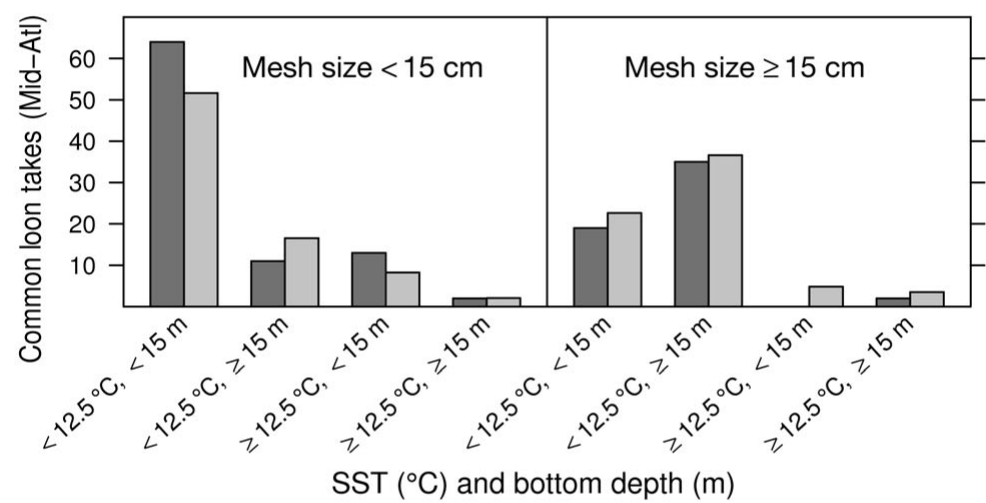
and aided in achieving equidispersion $(\hat{c}=$ 1.2).

\section{Mid-Atlantic}

The exploratory model for common loons in the Mid-Atlantic contained many of the same covariates as the top bycatch estimation models: depth, SST, and the 2 yr lag of WNAO. Additional gear characteristics in the exploratory model were soak duration (i.e. the length of time the string was in the water) and haul duration (i.e. the length of the haulback time). The $\triangle$ QAIC when omitting either variable was $>30$, providing strong support for their association with the bycatch rate. GAM smoothers indicated that short soak durations $(<24 \mathrm{~h})$ were associated with lower bycatch rates than long soak durations, and short haul durations (<30 min) were associated with higher bycatch rates than long haul durations. Hauls with soak durations $<24 \mathrm{~h}$ accounted for about $46 \%$ of all observed landings but only about $20 \%$ of observed common loon takes. Haulbacks that lasted <30 min accounted for about $11 \%$ of landings and about $49 \%$ of takes.

In comparison to the top bycatch estima-

Fig. 3. Gavia immer and G. stellata. Observed takes versus modelaveraged, fitted takes for common loons in the Northeast (top) and Mid-

Atlantic (middle), and red-throated loons in the Mid-Atlantic (bottom)

tion model, the inclusion of relevant gear characteristics improved the mean structure of the model (evidence ratio for exploratory

Fishing characteristics

\section{Northeast}

The final exploratory model of characteristics associated with common loon bycatch in the Northeast included depth, distance from the coast, SST, and an indicator of whether a space of at least 2 feet $(\sim 60 \mathrm{~cm})$ was used between nets. The $\triangle$ QAIC when omitting the space variable was $>14$, providing strong support for model against top bycatch estimation model fit to same dataset $=99$ ) and reduced the estimated dispersion parameter by about half $(\hat{c}=2.8)$.

\section{Potential biological removal}

PBR for common loons was 8719 (95\% CI: $7170-$ 9905) for $\alpha=4$ and 6424 (5371-7206) for $\alpha=6$ (Table 6 ). PBR for red-throated loons ranged from 1075 (875-1230) 
Table 6. Gavia immer and G. stellata. Estimated annual population growth rate under optimal conditions ( $\lambda_{\max i}$ Eq. 3) and potential biological removal (PBR; Eq. 1) calculated under various demographic parameters for common loons and red-throated loons. na: not available. Table modeled after Žydelis et al. (2009)

\begin{tabular}{|c|c|c|c|c|c|c|c|c|}
\hline & \multirow{2}{*}{$\begin{array}{l}\text { Age at first } \\
\text { breeding } \\
(\alpha)\end{array}$} & \multicolumn{2}{|c|}{$\begin{array}{l}\text { Adult survival } \\
\text { rate }\end{array}$} & \multirow{2}{*}{$\begin{array}{l}\text { Recovery } \\
\text { factor } \\
(f)\end{array}$} & \multicolumn{2}{|c|}{$\begin{array}{l}\text { Maximum population } \\
\text { growth rate }\end{array}$} & \multicolumn{2}{|c|}{$\begin{array}{c}\text { Potential biological } \\
\text { removal }\end{array}$} \\
\hline & & $s$ & $95 \%$ CI & & $\lambda_{\max }$ & $95 \%$ CI & PBR & $95 \%$ CI \\
\hline Common loon ${ }^{\mathrm{a}}$ & $\begin{array}{l}4^{\mathrm{b}} \\
6^{\mathrm{c}}\end{array}$ & $\begin{array}{l}0.92 \\
0.92\end{array}$ & $\begin{array}{l}(0.89,0.95) \\
(0.89,0.95)\end{array}$ & $\begin{array}{l}0.5 \\
0.5\end{array}$ & $\begin{array}{l}1.13 \\
1.09\end{array}$ & $\begin{array}{l}(1.10,1.14) \\
(1.08,1.10)\end{array}$ & $\begin{array}{l}8719 \\
6424\end{array}$ & $\begin{array}{l}(7170,9905) \\
(5371,7206)\end{array}$ \\
\hline Red-throated loon ${ }^{\mathrm{d}}$ & $\begin{array}{l}3 \\
3 \\
3\end{array}$ & $\begin{array}{l}0.84^{\mathrm{e}} \\
0.89^{\mathrm{f}} \\
0.92^{\mathrm{g}}\end{array}$ & $\begin{array}{c}\text { na } \\
(0.87,0.91) \\
(0.89,0.95)\end{array}$ & $\begin{array}{l}0.3 \\
0.3 \\
0.3\end{array}$ & $\begin{array}{l}1.21 \\
1.18 \\
1.16\end{array}$ & $\begin{array}{c}\text { na } \\
(1.16,1.19) \\
(1.13,1.17)\end{array}$ & $\begin{array}{l}1440 \\
1230 \\
1075\end{array}$ & $\begin{array}{c}\text { na } \\
(1130,1320) \\
(875,1230)\end{array}$ \\
\hline
\end{tabular}

to 1440 (95\% CI not available because adult survival CI not available; Table 6) with the various adult survival parameters.

\section{DISCUSSION}

\section{Unexplained uncertainty}

The uncertainty involved in adjusting the VTR landings with the CFDBS landings was not taken into account when assessing model uncertainty. About $75 \%$ of VTR trips from the Northeast and half from the Mid-Atlantic were matched to CFDBS transactions, so no added uncertainty is associated with the landings for those trips. Landings for the unmatched records, however, would have additional unknown amounts of uncertainty.

Missing covariate values also add to unexplained variability. Missing values in the observer data were rare, but $10 \%$ of VTR data were missing detailed locations. Within the strata used to fill in missing locations, however, non-missing longitude and latitude values had low variation (as measured by the CVs), implying well-specified strata. The median and regression methods that were used can generate good point estimates of missing values (Little \& Rubin 2002), even though they ignore the replacement values' uncertainty. To avoid invalid inferences based on underestimated standard errors, AIC was used for model selection, and bootstrapping was used to assess model uncertainty.

\section{Overdispersion}

Overdispersion was mainly a problem in the MidAtlantic common loon bycatch estimation models (global $\hat{c}=5.6$ ). Cameron \& Trivedi (1998) stated that the estimated regression coefficients are consistent (i.e. they converge in probability to the true coefficients) for an overdispersed model when the mean structure is adequate. Since all models with an inadequate mean structure (i.e. $\hat{c} \geq 6$ ) were eliminated, it is assumed that the model coefficients are consistent and so they are reliable estimates of the bycatch rate. Estimated overdispersion was variable depending on the choice of predictors (Table 5), which suggests that the unexplained variability was at least partly due to unobserved heterogeneity amongst observed hauls. This was borne out in the exploratory model that included relevant fishing characteristics.

\section{Observer protocol}

On-watch or off-watch protocols are in effect on a gillnet haul. If on-watch, the observer watches the net during the entire haulback. If off-watch, the observer samples the catch during haulback, recording incidental bycatch only if an animal is hauled onboard. Animals that fall out of the net before being hauled onboard are recorded by the observer on on-watch hauls but would be missed on off-watch hauls unless reported by the crew. Bravington \& Bisack (1996) found that the observer protocol had a significant effect on estimated bycatch rates of harbor porpoise Phocoena phocoena during the early years of the observer program, but it is unsure whether this is true for seabirds. The present analysis does not remove observed hauls or adjust bycatch mortality based on observer protocol; therefore, it is possible that estimates are biased downwards because birds may fall out of the net before being brought onboard. $\stackrel{2}{2}$ An indicator for observer pro-

\footnotetext{
$\underline{2}$ The Northeast Fisheries Observer Program documented 3 red-throated loons (1 each in 1999, 2002, and 2005) and 2 unidentified loons (both on the same haul in 2002) as having fallen out of the net during on-watch hauls
} 
tocol was tested in the exploratory models and was not found to have a relationship with common loon bycatch, once other important gear and haul characteristics were taken into account (evidence ratio $=1.3$ in the Mid-Atlantic and 0.4 in the Northeast).

\section{Estimated bycatch, related fishing characteristics, and potential biological removal}

The effect of fisheries bycatch on USA Atlantic seabird populations is poorly understood. The present analyses show that the average annual bycatch of 551 common loons was $\sim 9 \%$ of PBR calculated with the average age at first breeding. The average annual bycatch of 897 red-throated loons was $~ 62 \%$ of PBR calculated with demographic parameters from European red-throated loon populations.

One could instead compare the 2001 to 2007 average annual bycatch to PBR because average annual bycatch was lower for 2001 to 2007 than for 1996 to 2000 (approximately 300 versus 900 common loons and 600 versus 1300 red-throated loons, respectively). The lower bycatch magnitude was partly due to effort reduction in the Mid-Atlantic (Table 2) and possibly to moratoriums on ocean-intercept shad fisheries. For the later time period, average annual common loon bycatch was $\sim 5 \%$ of PBR and red-throated loon bycatch was $\sim 42 \%$ of PBR.

Two aspects of the \% of PBR should be noted: mortality estimates that are compared to PBR must include all human-caused mortality, not only bycatch mortality, and the reported bycatch estimates should not be considered complete estimates of common and redthroated loon bycatch in all USA east coast gillnet fisheries. Many fisheries in inshore bays and estuaries were not included in the analysis. The reported estimates may also be biased lower by an undetermined amount because 70 loons not identified to the species level in the NEFOP database were not included in the analysis. Bycatch in other USA Atlantic fisheries, although rare, was also not included. $\underline{3}$

Currently, seabird bycatch in USA Atlantic fisheries is not addressed by fisheries management measures. The common loon bycatch exploratory models suggest that the bycatch rate may be related to fishing characteristics such as spaces between nets, haul duration, and soak duration. The reason for lower bycatch on strings with spaces between nets compared to otherwise configured nets may be that the spaces allow birds

${ }^{3}$ The Northeast Fisheries Observer Program observed 4 loon bycatch mortalities in other fisheries during 1996 to 2007 : 1 red-throated loon and 1 common loon in beach seine gear, and 1 common loon and 1 unidentified loon in scallop dredges to pass through the gillnet string. It is possible, however, that spacing between nets is more common with some fishing practices than others, and the true mechanism lies with the unaccounted-for fishing practice. It may also be a purely statistical association. The association between the haul duration and the bycatch rate might also be explained by other factors. Strings with short haul times (<30 min) are generally located closer to the coast than strings with longer haul times (mean distance in NEFOP data $=6.8$ versus $20.2 \mathrm{~km}$ ), making them more likely to interact with common loons. Gillnet strings with spaces between the nets do not tend to be closer or farther from shore than strings without spaces $($ mean $=13.9$ versus $13.8 \mathrm{~km})$. Strings with short soak durations $(<24 \mathrm{~h})$ tend to be closer to the coast than strings with longer soak durations (mean $=8.2$ versus $23.8 \mathrm{~km}$ ), yet they are associated with a lower common loon bycatch rate. This finding suggests that soak duration might be a viable unit of effort for gillnet fisheries if it were well represented in VTR data.

If future conservation engineering is to be considered to reduce seabird bycatch in USA Atlantic gillnet fisheries, then further research using designed and controlled experimental procedures is needed to confirm whether gillnet strings with spaces between nets or with short soak durations result in reduced common loon or other seabird bycatch. The \% of PBR for redthroated loon bycatch emphasizes the importance of obtaining more information on stock-specific demographic parameters and on bycatch in inshore gillnet fisheries that are underrepresented in NEFOP data.

Acknowledgements. I thank NEFOP observers and data editors for collecting the data used in this analysis. I also thank C. Orphanides for processing GIS data; G. Magnusson and M. Rossman for advice on commercial fisheries databases; R. Merrick, T. Miller, K. Murray, and 4 anonymous reviewers for reviewing the manuscript; and D. Palka for statistical advice and reviewing the manuscript.

\section{LITERATURE CITED}

Agresti A (1996) An introduction to categorical data analysis. Wiley \& Sons, New York

ASMFC (Atlantic States Marine Fisheries Commission) (1999) Amendment 1 to the Interstate Fishery Management Plan for Shad \& River Herring. Fishery Management Report No. 35. Washington, DC

Balance LT, Ainley DG, Hunt GL Jr (2001) Seabird foraging ecology. In: Steele JH, Thorpe SA, Turekian KK (eds) Encyclopedia of ocean sciences, Vol 5. Academic Press, London, p 2636-2644 doi:10.1006/rwos.2001.0233

> Benjamins S, Kulka DW, Lawson J (2008) Incidental catch of seabirds in Newfoundland and Labrador gillnet fisheries, 2001-2003. Endang Species Res 5:149-160

Bravington MV, Bisack KD (1996) Estimates of harbor porpoise bycatch in the Gulf of Maine sink gillnet fishery, 1990-1993. Rep Int Whaling Comm 46:567-574 
Burnham KP, Anderson DR (2002) Model selection and multimodel inference: a practical information-theoretic approach, 2nd edn. Springer, New York

Cameron AC, Trivedi PK (1998) Regression analysis of count data. Cambridge University Press, Cambridge

Carretta JV, Price T, Petersen D, Read R (2004) Estimates of marine mammal, sea turtle, and seabird mortality in the California drift gillnet fishery for swordfish and thresher shark, 1996-2002. Mar Fish Rev 66:21-30

Dagys M, Žydelis R (2002) Bird bycatch in fishing nets in Lithuanian coastal waters in wintering season 2001-2002. Acta Zool Litu 12:276-282

Definitions (1973) 50 C.F.R. Sec 10.12 (available at: http:// edocket.access.gpo.gov/cfr_2009/octqtr/50cfr10.12.htm, accessed 26 Aug 2010)

> DeGange AR, Day RH (1991) Mortality of seabirds in the Japanese land-based gillnet fishery for salmon. Condor 93:251-258

Dillingham PW, Fletcher D (2008) Estimating the ability of birds to sustain additional human-caused mortalities using a simple decision rule and allometric relationships. Biol Conserv 141:1783-1792

> Dunn PK, Smyth GK (1996) Randomized quantile residuals. J Comput Graph Stat 5:236-244

> Durant JM, Anker-Nilssen T, Hjermann D, Stenseth NC (2004) Regime shifts in the breeding of an Atlantic puffin population. Ecol Lett 7:388-394

Evers DC (2007) Status assessment and conservation plan for the common loon (Gavia immer) in North America. BRI Report 2007-20. US Fish and Wildlife Service, Hadley, MA

Forsell DJ (1999) Mortality of migratory waterbirds in MidAtlantic coastal anchored gillnets during March and April, 1998. US Fish and Wildlife Service, Annapolis, MD

Gotthardt T (2001) Status report on the red-throated loon (Gavia stellata). Alaska Natural Heritage Program, Environment and Natural Resources Institute, University of Alaska, Anchorage

Grear JS, Meyer MW, Cooley JH Jr, Kuhn A and others (2009) Population growth and demography of common loons in the northern United States. J Wildl Manag 73:1108-1115

> Groves DJ, Conant B, King RJ, Hodges JI, King JG (1996) Status and trends of loon populations summering in Alaska, 1971-1993. Condor 98:189-195

Hamel NJ, Parrish JK, Laake J (2008) Linking colonies to fisheries: spatio-temporal overlap between common murres (Uria aalge) from Tatoosh Island and coastal gillnet fisheries in the Pacific Northwest, USA. Biol Conserv 141: $3101-3115$

Haney CJ (1990) Winter habitat of common loons on the continental shelf of the southeastern United States. Wilson Bull 102:253-263

Hemmingsson E, Eriksson MOG (2002) Ringing of redthroated diver Gavia stellata and black-throated diver Gavia arctica in Sweden. Diver/Loon Specialist Group, Wetlands International, Newsletter, Vol 4

Hurrell JW (1995) Decadal trends in the North Atlantic Oscillation: regional temperatures and precipitation. Science 269:676-679

Kutner MH, Nachtsheim CJ, Neter J, Li W (2005) Applied linear statistical models, 5th edn. McGraw-Hill/Irwin, New York

Little RJA, Rubin B (2002) Statistical analysis with missing data, 2nd edn. Wiley \& Sons, Hoboken, NJ

MBTA (Migratory Bird Treaty Act) (1918) 16 U.S.C. Secs. 703712 (available at: http://frwebgate.access.gpo.gov/cgi-bin/ usc.cgi?action=browse \&title=16uscc $7 \&$ pdfs=yes, accessed 26 Aug 2010)
McIntyre JW (1978) Wintering behavior of common loons. Auk 95:396-403

Melvin EF, Parrish JK (2001) Preface. In: Melvin EF, Parrish JK (eds) Seabird bycatch: trends, roadblocks, and solutions. University of Alaska Seagrant, Fairbanks, p v-vii

Melvin EF, Parrish JK, Conquest LL (1999) Novel tools to reduce seabird bycatch in coastal gillnet fisheries. Conserv Biol 13:1386-1397

> Mitro MG, Evers DC, Meyer MW, Piper WH (2008) Common loon survival rate and mercury in New England and Wisconsin. J Wildl Manag 72:665-673

Moore JE, Wallace BP, Lewison RL, Žydelis R, Cox TM, Crowder LB (2009) A review of marine mammal, sea turtle and seabird bycatch in USA fisheries and the role of policy in shaping management. Mar Policy 33:435-451

MSRA (Magnuson-Stevens Fishery Conservation and Management Reauthorization Act of 2006) (2007) 16 U.S.C. Secs. 1801-1891 (available at: http://frwebgate.access.gpo. gov/cgi-bin/usc.cgi?action=browse \&title=16uscc38\&pdfs= yes, accessed 26 Aug 2010)

Murray KT (2009) Characteristics and magnitude of sea turtle bycatch in US mid-Atlantic gillnet gear. Endang Species Res 8:211-224

Niel C, Lebreton JD (2005) Using demographic invariants to detect overharvested bird populations from incomplete data. Conserv Biol 19:826-835

> Nilsson SG (1977) Adult survival rate of the black-throated diver Gavia arctica. Ornis Scand 8:193-195

NMFS (National Marine Fisheries Service) (2000) Fisheries of the northeastern United States; Spiny dogfish fishery management plan. Fed Regist 65(7):1557-1571

Orphanides CD, Palka DL (2007) Landings: the unit of effort for bycatch rates in gillnet fishing gear. Harbor Porpoise Take Reduction Team (HPTRP) meeting materials. Binder document 3d. National Marine Fisheries Service, Northeast Regional Office, Gloucester, MA

Orphanides CD, Palka DL (2008) Bycatch of harbor porpoises in three U.S. gillnet management areas: Southern MidAtlantic, Offshore, and Western Gulf of Maine. US Dept Commer, Northeast Fish Sci Cent Ref Doc 08-09

> Österblom H, Fransson T, Olsson O (2002) Bycatches of common guillemot (Uria aalge) in the Baltic Sea gillnet fishery. Biol Conserv 105:309-319

Palmer MC, Wigley SE (2009) Using positional data from Vessel Monitoring Systems to validate the logbook-reported area fished and the stock allocation of commercial fisheries landings. N Am J Fish Manag 29:928-942

$>$ Peduzzi P, Concato J, Kemper E, Holford TR, Feinstein AR (1996) A simulation study of the number of events per variable in logistic regression analysis. J Clin Epidemiol 49:1373-1379

Powers KD, Cherry J (1983) Loon migrations off the coast of the northeastern United States. Wilson Bull 95:125-132

R Development Core Team (2008) R: a language and environment for statistical computing. R Foundation for Statistical Computing, Vienna (available at: http://www.R-project.org)

> Rainio K, Laaksonen T, Ahola M, Vähätalo AV, Lehikoinen E (2006) Climatic responses in spring migration of boreal and arctic birds in relation to wintering area and taxonomy. J Avian Biol 37:507-515

RARR (Recordkeeping and reporting requirements) (1996) 50 C.F.R. Sec 648.7 (available at: http://edocket.access. gpo.gov/cfr_2009/octqtr/50cfr648.7.htm, accessed 26 Aug 2010)

Richards SA (2008) Dealing with overdispersed count data in applied ecology. J Appl Ecol 45:218-227

Sandvik H, Erikstad K (2008) Seabird life histories and 
climatic fluctuations: a phylogenetic-comparative time series analysis of North Atlantic seabirds. Ecography 31:73-83

Sherony DF, Ewald BM, Kelling S (2000) Inland fall migration of red-throated loons. J Field Ornithol 71:310-320

Smyth G (2008) Statmod: statistical modeling. R package version 1.3.6 (available at www.statsci.org/r)

Soczek ML (2006) An analysis of seabird bycatch in New England commercial fisheries. Master's thesis. Antioch University New England, Keene, NH

USFWS (US Fish and Wildlife Service) (2008) Birds of conservation concern 2008. US Dept Interior, Fish and Wildlife Service, Division of Migratory Bird Management, Arlington, VA (available at www.fws.gov/migratorybirds/)

Wade PR (1998) Calculating limits to the allowable human-

Editorial responsibility: William Sydeman,

Petaluma, California, USA caused mortality of cetaceans and pinnipeds. Mar Mamm Sci 14:1-37

Warden ML, Orphanides CD (2008) Preparation of the northeast fisheries observer program gillnet data for use in bycatch analyses of protected species. US Dept Commer, Northeast Fish Sci Cent Ref Doc 08-17 (available at: www. nefsc.noaa.gov/publications/crd/crd0817)

Wigley SE, Hersey P, Palmer JE (2008) A description of the allocation procedure applied to the 1994 to 2007 commercial landings data. US Dept Commer, Northeast Fish Sci Cent Ref Doc 08-18 (available at: www.nefsc.noaa.gov/ publications/crd/crd0818)

Žydelis R, Bellebaum J, Österblom H, Vetemaa M and others (2009) Bycatch in gillnet fisheries - an overlooked threat to waterbird populations. Biol Conserv 142:1269-1281

Submitted: October 12, 2009; Accepted: July 12, 2010 Proofs received from author(s): August 12, 2010 